\title{
Origin, diversity and distribution of freshwater epigean amphipods in Maghreb
}

\author{
Khaoula Ayati ${ }^{1}$, Ramzi Hadjab ${ }^{2}$, Hichem Khammar $^{2}$, Sonia Dhaouadi ${ }^{1}$, Christophe Piscart ${ }^{3, *}$ and \\ Ezzeddine Mahmoudi ${ }^{1}$ \\ ${ }^{1}$ Université de Carthage, Faculté des Sciences de Bizerte, LR01ES14 Bio Surveillance de l'Environnement, 7021 Bizerte, Tunisia \\ ${ }^{2}$ Faculté des Sciences Exacts et Sciences Naturelles, Université d’Oum EL Bouaghi, Oum El Bouaghi, Algeria \\ ${ }^{3}$ Univ Rennes, CNRS, ECOBIO UMR 6553, 35000 Rennes, France
}

Received: 17 March 2019; Accepted: 9 May 2019

\begin{abstract}
Northern Africa, although one of the world hotpots of biodiversity, is poorly studied and the freshwater fauna living in this part of the world remains partly unknown. This study focused on the diversity and distribution of the poorly known epigean freshwater amphipods. We performed an exhaustive analysis of the literature on this group of crustaceans and sampled 106 additional localities from the eastern part of Algeria and in Tunisia. Our results showed an important diversity with 25 species (including the presence of at least three new undescribed species) and a very high rate of endemism with $52 \%$ of species occurring at on only 1 or 2 sites. We also highlighted a very low diversity on each site with only $4.4 \%$ of sites harboring more than 1 species. The comparative distribution of certain species between Europe and Maghreb and also between the western and eastern part of Northern Africa allow us to discuss some hypotheses about the factors underlying this endemism and the biogeographical origin of species. However, our study revealed a general lack of knowledge in the region, especially in the South of Morocco and Algeria. Hence, more information would be needed to propose adapted conservation strategies of freshwater fauna in Maghreb.
\end{abstract}

Keywords: Amphipoda / biodiversity / biogeographical distribution / freshwater / Northern Africa

\section{Introduction}

The Mediterranean Basin is known as one of the world's biodiversity hotspots (Myers et al., 2000). Its freshwater harbors $35 \%$ of Palearctic freshwater species and more than $6 \%$ of the world freshwater biodiversity with a very high rate of endemic species (Tierno de Figueroa et al., 2013). This exceptional biodiversity is strongly threatened by anthropogenic pressure such as the destruction of habitat, biological invasions and climate change which may become the most important factor of the biodiversity decline (Sala et al., 2000; Pereira et al., 2010; Caro et al., 2012). The biodiversity loss related to climate change may reach $39 \%$ to $43 \%$ of the world endemic species (Malcolm et al., 2006).

Among Mediterranean countries, countries in Maghreb are very affected by anthropogenic impacts and have to deal with combined effects of both climate change and overexploitation of freshwater resources (Romagny and Cudennec, 2006). It is therefore very urgent to define conservation priorities using credible information on biodiversity which, unfortunately, remain acutely scarce in this part of the world. This is

\footnotetext{
*Corresponding author: christophe.piscart@univ-rennes1.fr
}

especially true for aquatic invertebrates, even if they represent at least $80 \%$ of the world's freshwater species (Balian et al., 2008). This group is much less studied than other groups such as fish or amphibians (Dudgeon, 2000). As a consequence, information concerning extinction rates or just species inventories remains lacking for most of freshwaters (Palmer et al., 2000).

In this study, we worked with freshwater epigean amphipods. This group is much diversified in inland waters with more than 2400 known species over the world (WORMS, 2019). It also inhabits diverse kinds of freshwater environments (running waters, lakes, ground waters) in which they represent the leading invertebrate biomass (Navel et al., 2010; Piscart et al., 2009b, 2011). As their life cycle is entirely aquatic, they are also particularly threatened by climate change, contrary to insects which have a flying adult stage to avoid drought events (Aspin et al., 2019).

In Maghreb, knowledge on freshwater amphipods is rather limited and consists mainly of few taxonomic works (Karaman and Pinkster, 1977; Kayo et al., 2012; Pinkster, 1993; Rewicz et al., 2014). We currently know 22 species able to colonize freshwaters (Ayati et al., 2018; Rewicz et al., 2014). All those species belong to the family Gammaridae, more precisely into four genera: Echinogammarus Stebbing, 1899 (13 species); 


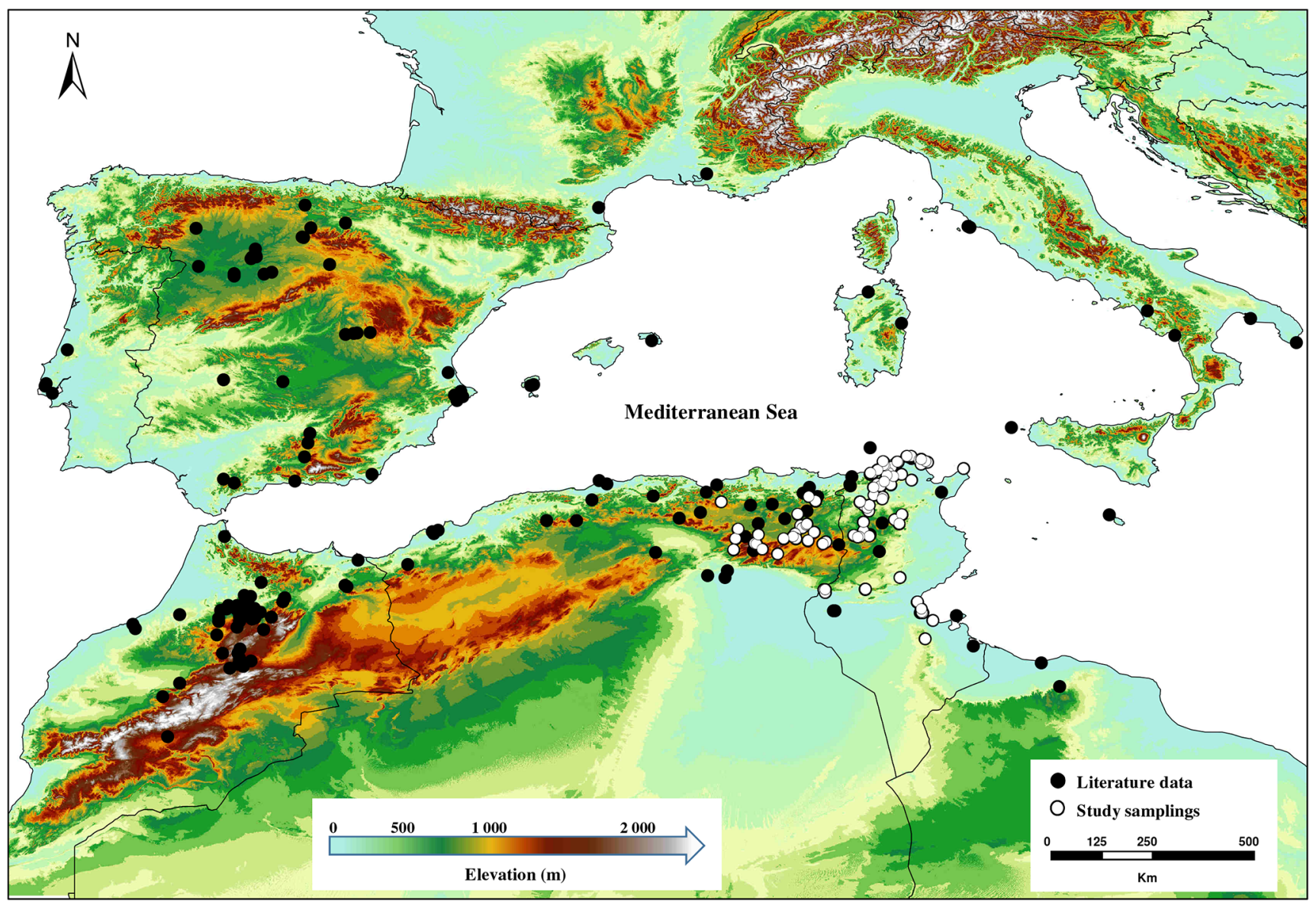

Fig. 1. Location of our sites and sites from literature.

Gammarus Fabricus, 1775 (7 species); Chaetogammarus Martynov, 1924 (1 species); Rhipidogammarus Stock, 1971 (1 species). The genus Echinogammarus is the most diversified and divided into three groups of species (Echinogammarusberilloni, -pungens, and -simoni groups). Recently, the taxonomic position of species from these groups has been a subject of debate (Hou and Sket, 2016; Sket and Hou, 2018). From their molecular studies, these authors proposed the genus Homoeogammarus (Schellenberg, 1937) as a valid name and to consider species of the Echinogammarus simoni group as members of this genus (Hou and Sket, 2016). However, the diagnosis of the genus provided did not match the morphological description of the species recently described (Ayati et al., 2018). The lack of clear morphological diagnosis of the genus Homoeogammarus, acknowledged by the authors themselves (Sket and Hou, 2018) and the few number of species from Northern Africa taken into account in these studies are not sufficient to clearly solve this issue. We hence decided to keep the Echinogammarus groups in our study.

In this context, the goal of our study is to complete the existing knowledge on the diversity and the distribution of epigean freshwater amphipods in Maghreb. To do this, we summarized all the published literature and made additional samplings in Algeria and Tunisia. The comparison of old/ recent information with our new dataset allows us to better understand the present biogeographical distribution of species in this part of the world.

\section{Material and methods}

\subsection{Study area}

Our study focusses on Maghreb (Morocco, Algeria, and Tunisia) representing around $3,000,000 \mathrm{~km}^{2}$ of total area. These countries belong to the Mediterranean area of the Paleartic and are characterized by hot climates ranging from the hot desert climate in the South to the hot Mediterranean Climate in the North (Peel et al., 2007). The three countries are also linked by the Atlas Mountains, which occupy a large part of Morocco, Northern Algeria and Tunisia with Djebel Toubkal $(4167 \mathrm{~m})$ in Morocco as the highest peak. Most rivers and streams flow on the North face of the Atlas Mountains and are also characterized by a high rate of intermittence (Schneider et al., 2017).

\subsection{Data on amphipods}

An exhaustive survey of literature on freshwater epigean amphipods (species descriptions, identification keys, monography, $\mathrm{PhD}$ theses, books, and papers) has been done for all species known in Maghreb. For species known from both Europe and Maghreb, European localities were also taken into account (Fig. 1), except for Echinogammarus pungens inhabiting a great number of localities from Catalonia to Greece and for which we 
Table 1. Faunal list of epigean amphipods known in Maghreb. Litterature used to determine the distribution area are: $1=$ Ayati et al. $(2018) ; 2=$ Chevreux (1894); 3 = Chevreux and Fage (1925); $4=$ Fadil and Dakki (2001); $5=$ Fadil and Dakki (2003); $6=$ Fadil and Dakki (2006); $7=$ Fadil et al. (2009); $8=$ Gauthier (1928); $9=$ Karaman (1993); $10=$ Karaman (1935); $11=$ Karaman and Pinkster (1977); 12= Pinkster (1971); 13= Pinkster (1993); $14=$ Piscart et al. (2013); $15=$ Rewicz et al. (2014); 16= Hou and Sket (2016).

\begin{tabular}{|c|c|c|}
\hline Genus & Species & References \\
\hline \multirow{10}{*}{ Echinogammarus Stebbing, 1899} & E. annandalei (Monod, 1924) & 8,13 \\
\hline & E. dactyus G. Karaman, 1987 & 13 \\
\hline & E. haraktis Piscart, Merzoug, Hafid, 2013 & 14 \\
\hline & E. klaptoczi Schäferna, 1908 & 13 \\
\hline & E. pungens (H. Milne Edwards, 1840) & 13,15 \\
\hline & E. reductus Pinkster, 1993 & 13 \\
\hline & E. simoni (Chevreux, 1894) & $2,8,13,16$ \\
\hline & E. tacapensis (Chevreux and Gauthier, 1924) & 13 \\
\hline & E. tunetanus Ayati, Dhaouadi, Mahmoudi, Piscart, 2018 & 1 \\
\hline & E. valedictus Pinkster and Platvoet, 1990 & 13 \\
\hline \multirow{6}{*}{ Gammarus Fabricus, 1775} & G. gauthieri (S. Karaman, 1935) & $7,8,10,11,12$ \\
\hline & G. marmouchensis Fadil and Dakki, 2006 & 6 \\
\hline & G. maroccanus Fadil and Dakki, 2001 & 4 \\
\hline & G. microps Pinkster and Goedmakers, 1975 & 11 \\
\hline & G. riftalensis Fadil and Dakki, 2006 & 6 \\
\hline & G. rouxi Pinkster and Goedmakers, 1975 & 7,11 \\
\hline Chaetogammarus Martynov, 1924 & C. saisensis Fadil et al., 2009 & 7 \\
\hline Rhipidogammarus Stock, 1971 & R. rhipidiophorus (Catta, 1878) & $3,8,9$ \\
\hline
\end{tabular}

indicated the whole distribution area in Europe (Piscart and Bollache, 2012; Rewicz et al., 2014). For Gammarus gauthieri, localities provided by Karaman and Pinkster (1977) in Algeria and Tunisia could not be confirmed neither in the literature cited by the authors nor with our own samplings in the same areas. So, these localities have been removed from our maps.

In order to complete existing knowledge, freshwater amphipods were collected in the East of Algeria (30 sites) and in Tunisia (76 sites) from 2016 to 2019 (Fig. 1). Amphipods were sampled using a hand net sampler (Ø $500 \mu \mathrm{m}$ mesh size) in all kinds of freshwater environment (sources, streams, lakes, reservoirs, and ponds). On each site, all habitats were prospected (stones, roots, macrophytes) to collect at least 10 amphipods (but generally, more than 30 animals were sampled).

Samples were preserved in $96 \%$ alcohol on the field. All amphipods were identified at the species level using a stereomicroscope Olympus SZX16 (Olympus ${ }^{\mathrm{TM}}$ ) and adapted identification keys (Karaman and Pinkster, 1977; Pinkster, 1993), updated with new descriptions (Ayati et al., 2018; Fadil and Dakki, 2003, 2006, 2001; Piscart et al., 2013). For some animals, microscopic slides were used to confirm the identification (see Ayati et al., 2018 for details on microscopic preparation).

\subsection{Data analysis}

All maps were realized with ArcGis Desktop 10.4 software (Esfri ${ }^{\mathrm{TM}}$ ) and using GIS data available on DIVA website (http://www.diva-gis.org) or provided by (Schneider et al., 2017) and WGS 84 projection.

\section{Results}

Among the 22 species known in Maghreb (Tab. 1), only five species are also present in Europe. Echinogammarus simoni and Gammarus gauthieri are found in the Iberian Peninsula, Echinogammarus klaptoczi inhabits Balearic and Malta Islands, while Echinogammarus pungens and Rhipidogammarus rhipidiophorus are only known from localities very close to the Mediterranean Sea, from Catalonia to Greece and from Southeastern France to Sicily respectively. All other 17 species are native to Maghreb among which 10 are restricted to only one or two localities (Fig. 2). All these rare species are located on the Northern Face of the Atlas Mountains, except in few localities near Chottes Melrhir and El Djerid between Algeria and Tunisia. Another characteristic of amphipods in Maghreb is the very few number of species per site. Indeed, among the 274 locality recorded, only 12 


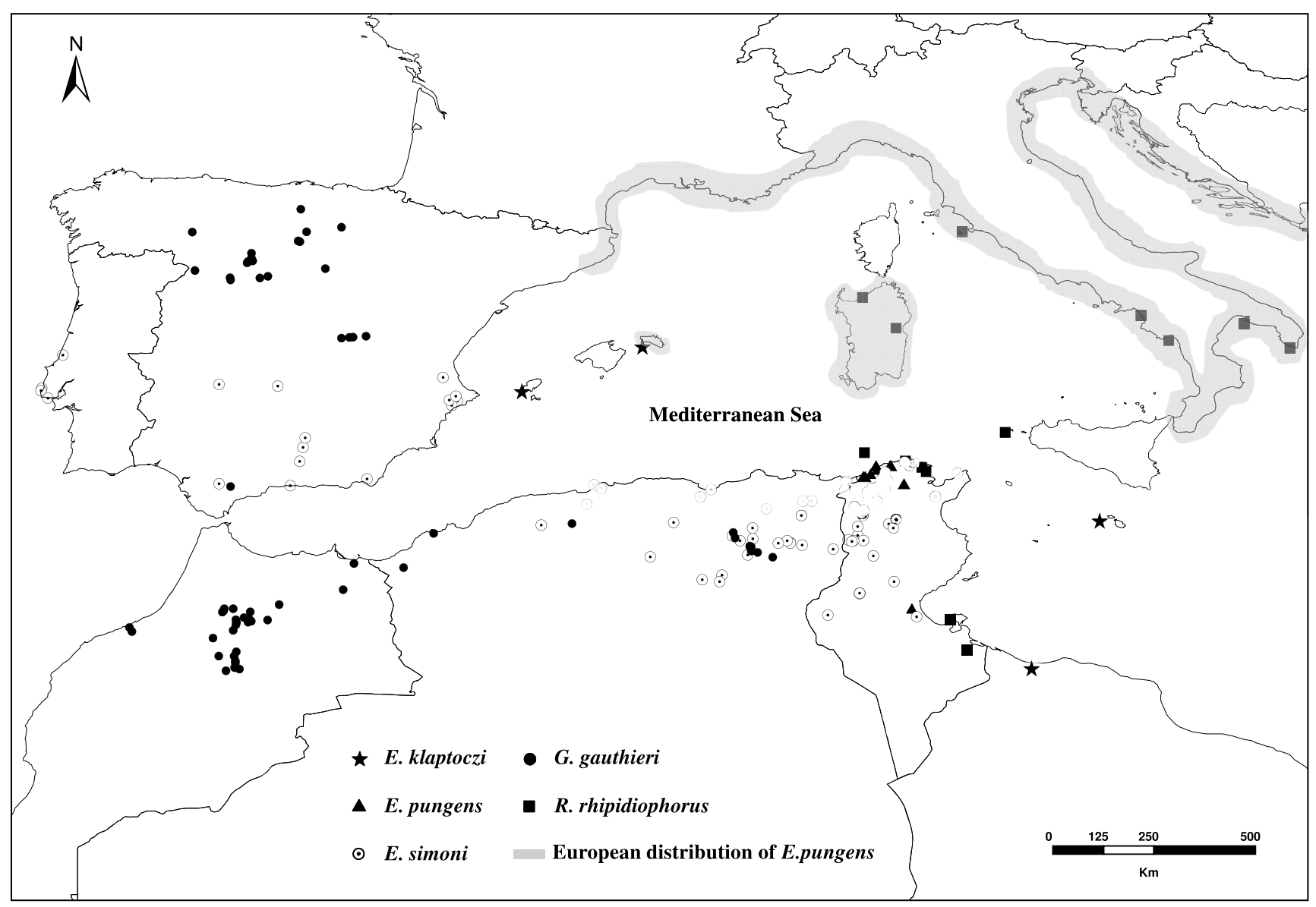

Fig. 2. Distribution of species present in Europe and Maghreb.

sites $(4.4 \%)$ harbored two species whereas all other sites are monospecific.

From a diversity point of view, the genus Echinogammarus is the most diversified with 13 known species and likely three new species from Algeria were discovered in our study (ongoing description). Among these species, 8 (50\% of the total richness of the genus) belong to the Echinogammarus simoni-group (Tab. 1). For this group, only E. simoni is widely distributed from Tunisia to Iberian Peninsula, all others having restricted distribution areas in Eastern Algeria and Tunisia (Fig. 3).

The Echinogammarus pungens-group is the second most diverse group with five species (Fig. 4). Echinogammarus pungens-group has only one species, E. pungens, widely distributed between Tunisia and the southern European coast (Fig. 2). However this species is always restricted to coastal streams and sources and was never found at more than $50 \mathrm{~km}$ from the Mediterranean Coast. The other species of this group are distributed throughout Maghreb but always on small distribution areas (Fig. 4). This group also harbors the only one Echinogammarus species from Morocco, Echinogammarus oujdae. Echinogammarus berilloni-group is the least diverse with only three species and in contrast to other groups of Echinogammarus, does not have common species between continental Europe and Maghreb because E. klaptoczy is known only in Libya and some Mediterranean Islands (Fig. 2). This group is distributed from East Algeria to Lybia (Fig. 4).

There are two other genera present in Maghreb with only one species each (Fig. 4). The genus Chaetogammarus with C. saisensis distributed only in the Saïss Vallee and Rift Mountains in the North of Morocco and the genus Rhipidogammarus with the species $R$. rhipidiophorus which is observed only in coastal sources very close (few meters) from the Mediterranean Sea in Tunisia and European coast from France to Italy.

Finally, the genus Gammarus is also well represented in Maghreb with 7 species known (Fig. 5), among which only $G$. gauthieri is widely distributed from Algeria to Spain (Fig. 2). All other species are only restricted to few localities on the North Face of Atlas Mountains in Morocco.

\section{Discussion}

Our study of the distribution of epigean freshwater amphipods in Maghreb confirms the important richness according to the scarcity of surface waters and a high rate of endemism in this part of the world (Tierno de Figueroa et al., 2013). With 13 rare species (considering the three potential new species) inhabiting in less than three localities among the 


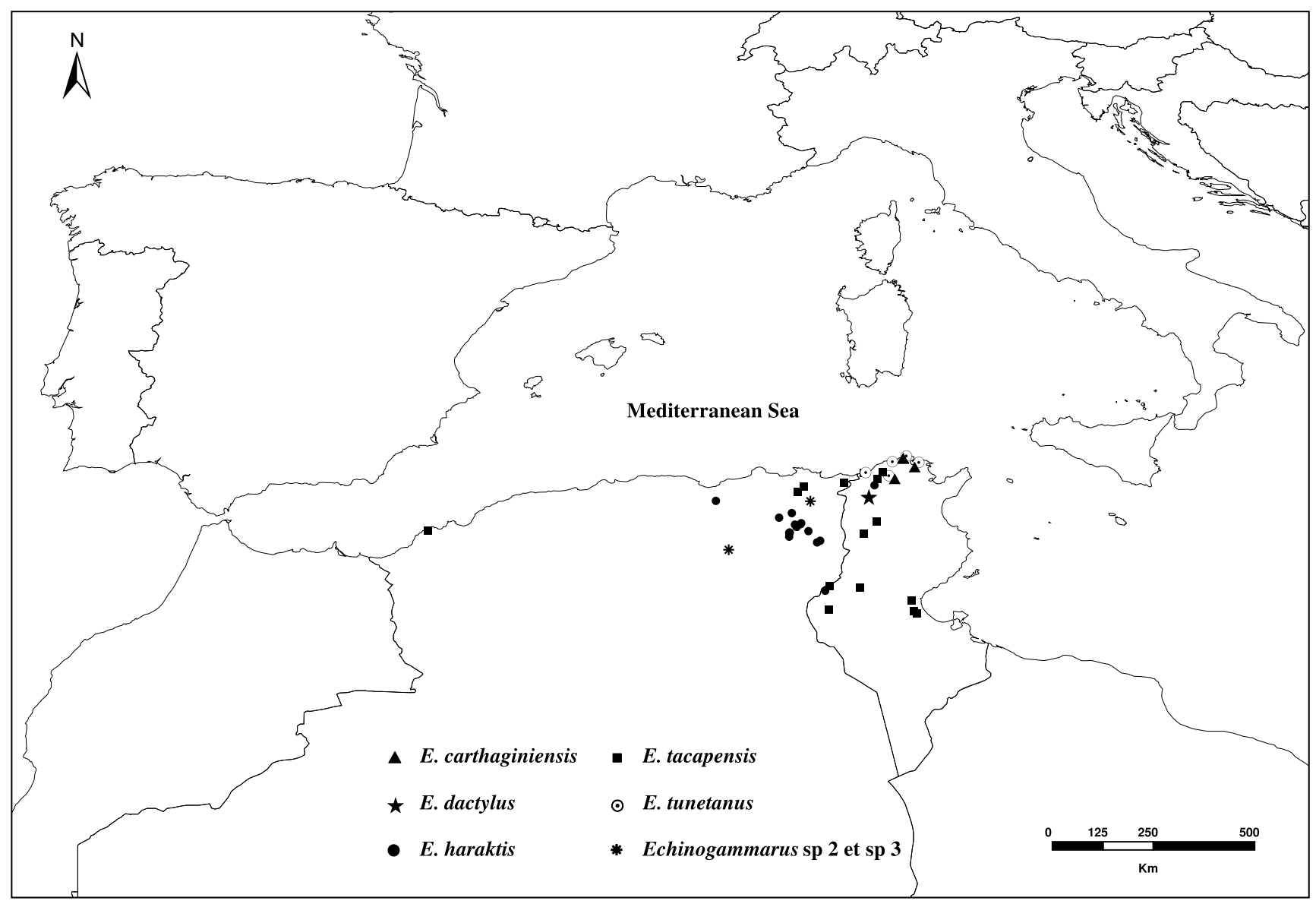

Fig. 3. Distribution of Echinogammarus simoni-group in Maghreb.

25 species, the rate of endemism in Maghreb (52\%) is much higher than the endemism in Europe $(\approx 20 \%)$ for epigean amphipods (Karaman and Pinkster, 1987, 1977; Karaman, 1993; Pinkster, 1993; Piscart and Bollache, 2012). Indeed, Maghreb was a refuge area during the last glacial periods (Husemann et al., 2014) and the high topographic heterogeneity due to the presence of Atlas Mountains impose geographical orographic barriers that limit the existence of wide distribution areas (Pleguezuelos et al., 2010). Another important factor to consider in studying the diversity of aquatic fauna in Maghreb is the limitation of the water resources during the last 6000 years (Schneider et al., 2017). This factor, in combination with interspecific interactions, may explain the very low species richness per site. Indeed, we know that interspecific interaction in amphipods may lead to the displacement or the disappearance of species locally (Piscart et al., 2007, 2009a, 2010). The scarcity of water could reduce the presence of refuge areas for species with low competitive abilities and the low species richness recorded could be the results of disappearance of the less competitive species in the very harsh environmental conditions in Maghreb. However, it is very difficult to confirm this hypothesis because amphipods do not leave fossil traces, contrary to Ostracods or Mollusks.

Another explanation for the endemism may be the lack of knowledge on the distribution of amphipods in Maghreb.
Indeed, Africa remains largely unknown for aquatic fauna, especially for crustaceans (Kayo et al., 2012) and the Amphipoda is itself one of the least known taxonomic group for which the rate of discovery increase regularly with $20 \%$ of the total number of known species described during the last 10 years (Arfianti et al., 2018). The lack of knowledge on the species distribution is also one of main justification of our study. However, our study, based on both extensive literature survey and complementary field samplings confirmed the high rate of endemism and the restricted distribution area of species, except for two species previously known only from the type locality. For E. valedictus, previously known from Djurdjura Mountains near Tizi Ouzou (Algeria), we found another locality near Batna at $270 \mathrm{~km}$ of Djurdjura Mountains and for Echinogammarus haraktis described near Oum El Bouaghi (Algeria), we found several new localities in Algeria and also in Tunisia at $300 \mathrm{~km}$ from the type locality. On the contrary, recent works in this region (Ayati et al., 2018; Piscart et al., 2014) showed that species with wide distribution areas such as E. simoni consist of several morphologically closely related species. In our study, the discovery of likely three new species during our samplings in Algeria, with two of these species (Echinogammarus sp2 and Echinogammarus sp3) belonging to the Echinogammarus simoni-group tend to validate the previous results. 


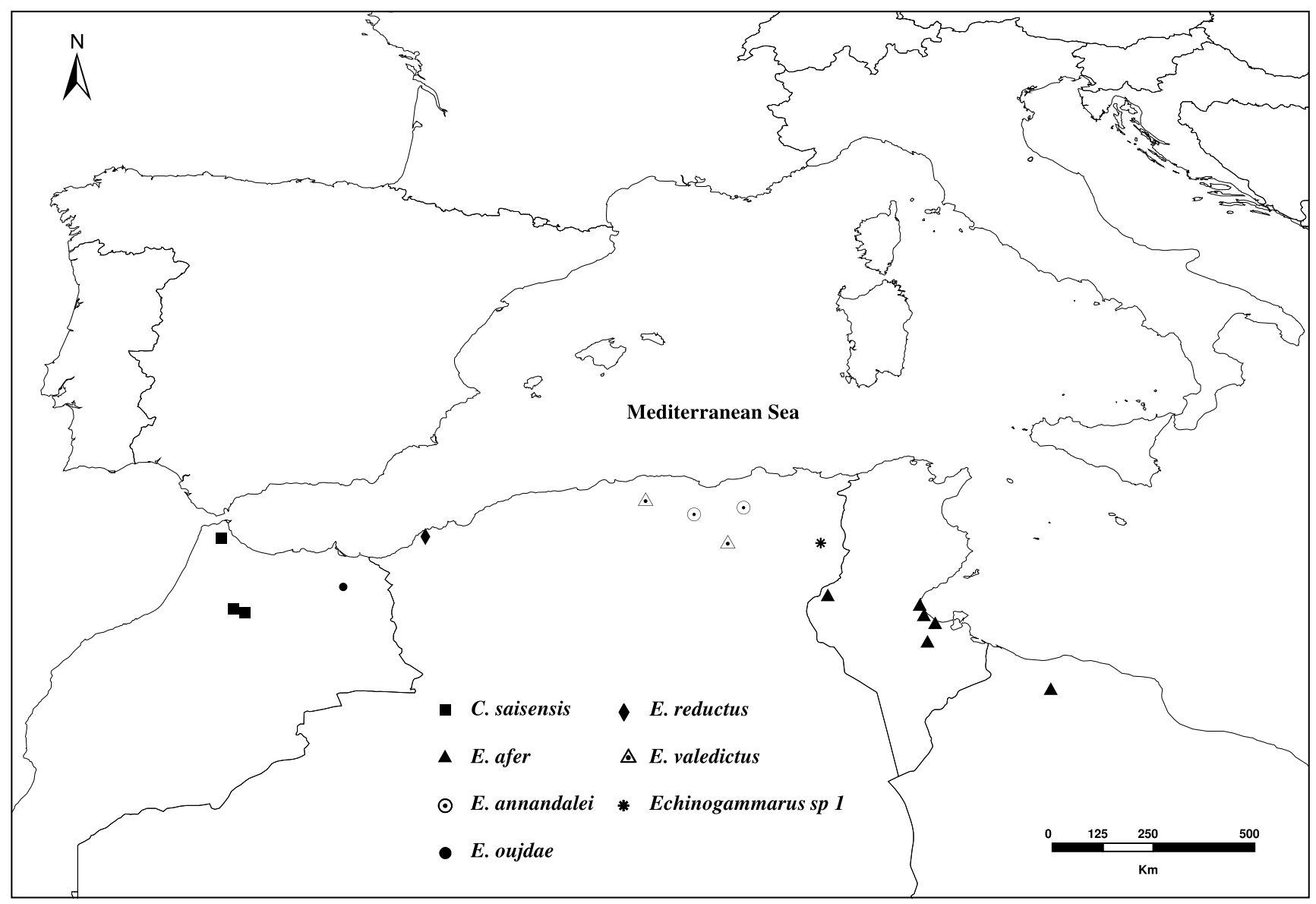

Fig. 4. Distribution of Echinogammarus berilloni- and Echinogammarus pungens-groups in Maghreb.

The origin of species in Maghreb is likely very old as suggested by the common species known in Europe and in Maghreb. The presence of the genus Gammarus, and especially G. gauthieri in Morocco and in Iberian Peninsula testifies an old exchange between these two regions. Indeed, Europe and Maghreb are separated by the Mediterranean Sea which represents a strong geographical barriers for most of non-flying animals. However, we know that the Mediterranean Sea was dry 5.5 million years ago during the messinian crisis (Hsü et al., 1977; Krijgsman et al., 1999) and several examples of exchanges between European and Maghrebian fauna during this period have been documented (Carranza et al., 2006; Guy-Haim et al., 2018; Stöck et al., 2012). In addition, some exchanges could be older. Indeed, phylogeographical analyses suggested the presence of the genus Gammarus in European freshwaters since at least 40 million years during the Eocene (Hou et al., 2011). The presence of the genus and the low depth of the Mediterranean Sea between Iberian Peninsula and Maghreb at the end of the Eocene (Meulenkamp and Sissingh, 2003) may have promoted the presence of G. gauthieri on both sides of the Mediterranean Sea. The distribution of E. simoni in Iberian Peninsula, East Algeria and Tunisia is more complex. The Messinian crisis may also promote the range expansion of the species in Maghreb but its absence in Morocco and, more generally, the under representation of the genus Echinogammarus in this country are not congruent with this hypothesis.
It is also unlikely that the establishment of the Echinogammarus simoni started from Sicily because this species is not present in Italy. The most plausible explanation is that the colonization of Maghreb by species of the genus Echinogammarus resulted from another geological event and could have possibly been from successive colonizations from Mediterranean marine species along Algerian or Tunisian coasts where the genus is the most diversified. Indeed, this genus is only known in freshwaters of Mediterranean Basin (Pinkster, 1993), that is congruent with a diversification from the Mediterranean Sea instead of a colonization during Messinian crisis (Barnard and Barnard, 1983; Hou and Sket, 2016).

For some species of Maghreb, the colonization from European Coasts is very recent and gene flow is still present (unpublished data). We suppose that it is the case for species living closed to the coast and on islands (E. klaptoczi, $E$. pungens, and $R$. rhipidiophorus). These three species colonized only a small stretch of freshwater close to the Mediterranean Sea and are mainly distributed in the eastern part of our study area. In addition, these species are known to have a high tolerance to salinity which explains their presence in the estuarine environment (Pinkster, 1993). The decrease of the sea level during the last glacial period $(-25,000$ years) may have reduced the distance between Europe and North Africa and fostered the exchange between salt tolerant populations. 


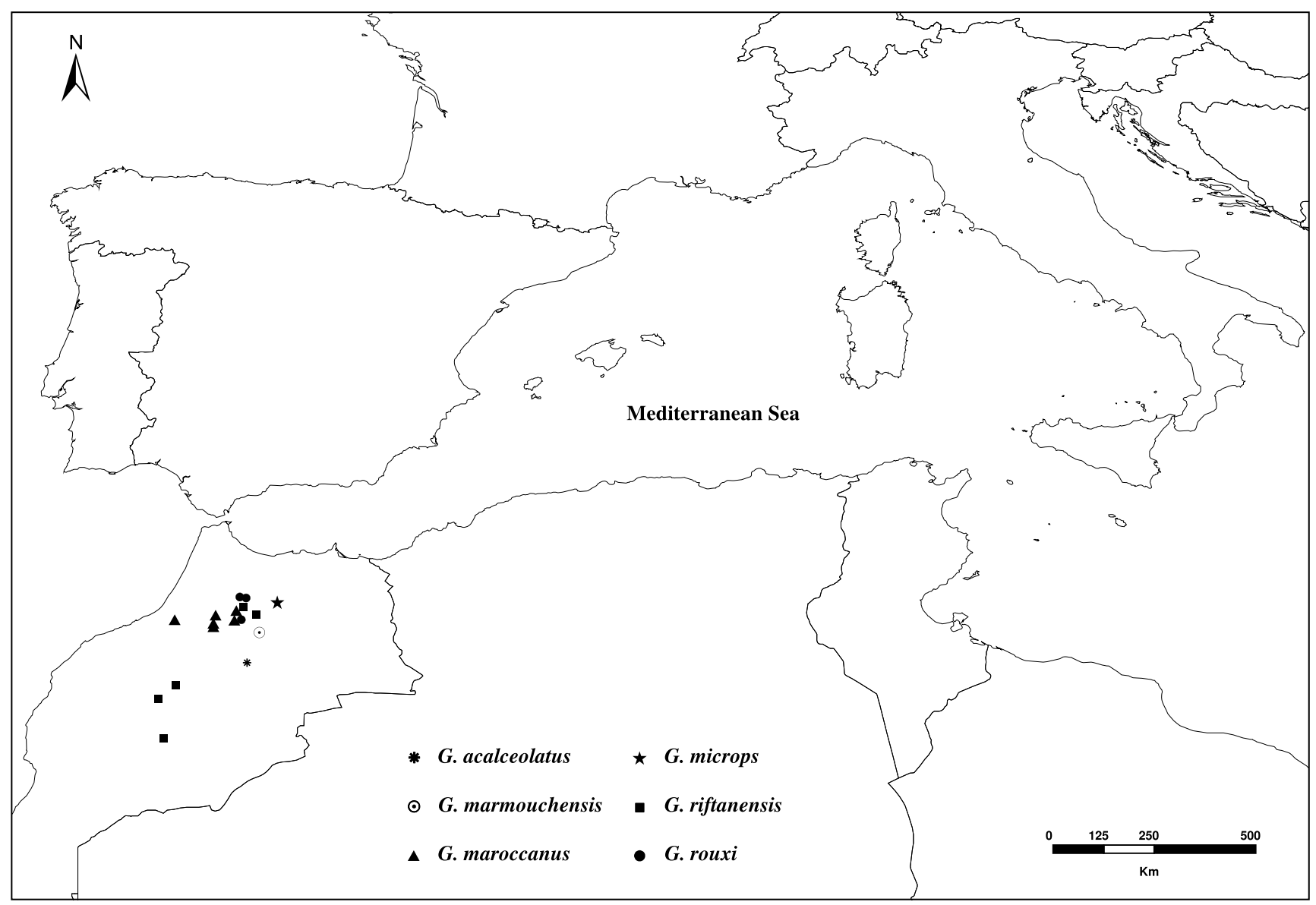

Fig. 5. Distribution of Gammarus species in Maghreb.

The distribution of these species in the Eastern Part of Maghreb suggests the use of the Sicily strait which is already known for the exchange of fauna between Europe and Maghreb before glacial period (Husemann et al., 2014) but also more recently during the glacial period (Habel et al., 2009, 2010; Stöck et al., 2008). Rewicz et al. (2014) proposed that the colonization of Tunisia by E. pungens might be the result of a recent invasion by this species from Europe. This hypothesis was based on the belief that this species is present in only one locality in Tunisia. However, our study clearly showed that the distribution of $E$. pungens is much more widespread in Tunisia and confirms that $E$. pungens must be considered as native form this country.

Our study proved the important biodiversity of epigean amphipods in Maghreb and clarified the origin of the 22 known species. Our results also highlighted the lack of knowledge in this part of the world with the discovery of several new species, even in the most well-known part of Maghreb. In regions where the threats on biodiversity are numerous, additional studies are recommended to define new and adapted conservation plans for freshwater fauna, especially in the South parts of Algeria and Morocco.

Acknowledgements. This study was supported by the University of Carthage (Tunisia) and the University d'Oum El Bouaghi (Algeria). We warmly thank our colleagues from
University of Lodz (Poland) for our exciting discussions about the distribution of Mediterranean amphipods. We also thank Pr Djemoi Merzoug (University of Oum El Bouaghi, Algeria) who initiated the survey of freshwater amphipods in Algeria.

\section{References}

Arfianti T, Wilson S, Costello MJ. 2018. Progress in the discovery of amphipod crustaceans. PeerJ 6: e 5187.

Aspin TWH, Khamis K, Matthews TJ, Milner AM, O’Callaghan MJ, Trimmer M, Woodward G, Ledger ME. 2019. Extreme drought pushes stream invertebrate communities over functional thresholds. Glob Change Biol 25: 230-244.

Ayati K, Dhaouadi S, Mahmoudi E, Piscart C. 2018. Two new species of gammarid amphipods from tunisian fresh waters (amphipoda, Gammaridae). Crustaceana 91: 1327-1345.

Balian EV, Segers H, Lévêque C, Martens K. 2008. An introduction to the Freshwater Animal Diversity Assessment (FADA) project. Hydrobiologia 595: 3-8.

Barnard JL, Barnard CM. 1983. Freshwater amphipoda of the world. Caro T, Darwin J, Forrester T, Ledoux-Bloom C, Wells C. 2012. Conservation in the Anthropocene. Conserv Biol 26: 185-188.

Carranza S, Harris DJ, Arnold EN, Batista V, De la Vega JPG. 2006. Phylogeography of the lacertid lizard, Psammodromus algirus, in Iberia and across the Strait of Gibraltar. J Biogeogr 33: 1279-1288. 
Chevreux E. 1894. Gammarus simoni, nov. sp., amphipode des eaux douces d'Algérie et de Tunisie. Bull Soc Zool Fr 19: 171-176.

Chevreux É, Fage L. 1925. Faune de France $n^{\circ} 9$, Amphipodes P, Lechevalier.

Dudgeon D. 2000. The ecology of tropical asian rivers and streams in relation to biodiversity conservation. Annu Rev Ecol Syst 31: 239-263.

Fadil F, Dakki M. 2001. Remarques sur la présence du genre Gammarus (Crustacés amphipodes) au Maroc, avec description d'une nouvelle espèce. Beaufortia 51: 153-161.

Fadil F, Dakki M. 2003. A new species of Echinogammarus Stebbing, 1899 (Crustacea, Amphipoda) from Moroccan freshwaters. Beaufortia 53: 53-59.

Fadil F, Dakki M. 2006. Deux espèces nouvelles du genre Gammarus (Crustacés, Amphipodes) du Maroc - PDF. Bull Inst Sci Rabat Sect Sci Vie 13-24.

Fadil F, Fadil K, Dakki M. 2009. A new species of Chaetogammarus Martynov, 1925 (Amphipoda) from Moroccan fresh waters, including notes on the Moroccan Epigean Gammaridae. Crustaceana 82: 969-979.

Gauthier H. 1928. Recherches sur la faune des eaux continentales de l'Algérie et de la Tunisie. PhD Thesis Université de Paris, 419 p. Guy-Haim T, Simon-Blecher N, Frumkin A, Naaman I, Achituv Y. 2018. Multiple transgressions and slow evolution shape the phylogeographic pattern of the blind cave-dwelling shrimp Typhlocaris. PeerJ 6: e 5268.

Habel JC, Dieker P, Schmitt T. 2009. Biogeographical connections between the Maghreb and the Mediterranean peninsulas of southern Europe. Biol J Linn Soc 98: 693-703.

Habel JC, Rödder D, Stefano S, Meyer M, Schmitt T. 2010. Strong genetic cohesiveness between Italy and North Africa in four butterfly species. Biol J Linn Soc 99: 818-830.

Hou Z, Sket B, Fišer C, Li S. 2011. Eocene habitat shift from saline to freshwater promoted Tethyan amphipod diversification. Proc Natl Acad Sci 108: 14533-14538.

Hou Z, Sket B. 2016. A review of Gammaridae (Crustacea: Amphipoda): the family extent, its evolutionary history, and taxonomic redefinition of genera. Zool J Linn Soc 176: 323-348.

Hsü KJ, Montadert L, Bernoulli D, Cita MB, Erickson A, Garrison RE, Kidd RB, Mèlierés F, Müller C, Wright R. 1977. History of the Mediterranean salinity crisis. Nature 267: 399.

Husemann M, Schmitt T, Zachos FE, Ulrich W, Habel JC. 2014. Palaearctic biogeography revisited: evidence for the existence of a North African refugium for Western Palaearctic biota. J. Biogeogr 41: 81-94.

Karaman G, Pinkster S. 1977. Freshwater gammarus species from Europe, North-Africa and adjacent regions of Asia (crustaceaAmphipoda). Part II. Gammarus-Roeseli-group and related species. Bijdr Tot Dierkd 47: 165-196.

Karaman G, Pinkster S. 1987. Fresh-water gammarus species from Europe, North-Africa and adjacent regions of Asia (crustacea, Amphipoda). Bijdr Tot Dierkd 57: 207-260.

Karaman GS. 1993. Fauna d'Italia. Amphipoda di acqua dolce 31, 31.

Karaman S. 1935. Rivulogammarus gauthieri n. sp., nouvel Amphipode dulçaquicole d'Algérie. Bull Société Hist Nat Afr Nord 26: 47-53.

Kayo RT, Marmonier P, Togouet SHZ, Nola M, Piscart C. 2012. An annotated checklist of freshwater stygobiotic crustaceans of Africa and Madagascar. Crustaceana 85: 1613-1631.

Krijgsman W, Hilgen FJ, Raffi I, Sierro FJ, Wilson DS. 1999. Chronology, causes and progression of the Messinian salinity crisis. Nature 400: 652.
Malcolm JR, Liu C, Neilson RP, Hansen L, Hannah L. 2006. Global warming and extinctions of endemic species from biodiversity hotspots. Conserv Biol J Soc Conserv Biol 20: 538-548.

Meulenkamp JE, Sissingh W. 2003. Tertiary palaeogeography and tectonostratigraphic evolution of the Northern and Southern PeriTethys platforms and the intermediate domains of the AfricanEurasian convergent plate boundary zone. Palaeogeogr Palaeoclimatol Palaeoecol 196: 209-228.

Myers N, Mittermeier RA, Mittermeier CG, da Fonseca GAB, Kent J. 2000. Biodiversity hotspots for conservation priorities. Nature 403: 853.

Navel S, Mermillod-Blondin F, Montuelle B, Chauvet E, Simon L, Piscart C, Marmonier P. 2010. Interactions between fauna and sediment control the breakdown of plant matter in river sediments. Freshw Biol 55: 753-766.

Palmer MA, Swan CM, Nelson K, Silver P, Alvestad R. 2000. Streambed landscapes: evidence that stream invertebrates respond to the type and spatial arrangement of patches. Landsc Ecol 15: 563-576.

Peel MC, Finlayson BL, McMahon TA. 2007. Updated world map of the Köppen-Geiger climate classification. Hydrol Earth Syst Sci 11: 1633-1644.

Pereira HM, Leadley PW, Proença V, Alkemade R, Scharlemann JPW, Fernandez-Manjarrés JF, Araújo MB, Balvanera P, Biggs R, Cheung WWL, Chini L, Cooper HD, Gilman EL, Guénette S, Hurtt GC, Huntington HP, Mace GM, Oberdorff T, Revenga C, et al. 2010. Scenarios for global biodiversity in the 21 st century. Science 330: 1496-1501.

Pinkster, S. 1971. Members of the Gammarus pulex-group (Crustacea - Amphipoda) from North Africa and Spain, with description of a new species from Morocco. Bull Zool Mus 2: 45-52.

Pinkster S. 1993. A revision of the genus Echinogammarus Stebbing, 1899, with some notes on related genera (Crustacea, Amphipoda). Mem Mus Civ Storia Nat Verona.

Piscart C, Manach A, Copp GH, Marmonier P. 2007. Distribution and microhabitats of native and non-native gammarids (Amphipoda, Crustacea) in Brittany, with particular reference to the endangered endemic sub-species Gammarus duebeni celticus. J Biogeogr 34: 524-533.

Piscart C, Dick JTA, McCrisken D, MacNeil C. 2009a. Environmental mediation of intraguild predation between the freshwater invader Gammarus pulex and the native G. duebeni celticus. Biol Invasions 11: 2141-2145.

Piscart C, Genoel R, Doledec S, Chauvet E, Marmonier P. 2009 b. Effects of intense agricultural practices on heterotrophic processes in streams. Environ Pollut 157: 1011-1018.

Piscart C, Bergerot B, Laffaille P, Marmonier P. 2010. Are amphipod invaders a threat to regional biodiversity? Biol Invasions 12: 853-863.

Piscart C, Navel S, Maazouzi C, Montuelle B, Cornut J, MermillodBlondin F, des Chatelliers MC, Simon L, Marmonier P. 2011. Leaf litter recycling in benthic and hyporheic layers in agricultural streams with different types of land use. Sci Total Environ 409: 4373-4380.

Piscart C, Bollache L. 2012. Crustacés amphipodes de surface (Gammare d'eau douce).

Piscart C, Merzoug D, Hafid H. 2013. A new species of Echinogammarus from Algerian fresh waters, Echinogammarus haraktis N. Sp (peracarida, Amphipoda). Crustaceana 86: 1623-1633.

Pleguezuelos JM, Brito JC, Fahd S, Feriche M, Mateo JA, MorenoRueda G, Reques R, Santos X. 2010. Setting conservation priorities 
for the Moroccan herpetofauna: the utility of regional red lists. Oryx 44: 501-508.

Rewicz T, Rachalewski M, Grabowski M. 2014. First record of Echinogammarus pungens (H. Milne Edwards, 1840) (Crustacea, Amphipoda) from Africa with the checklist of North African freshwater gammarids. Mediterr Mar Sci 15: 443-448.

Romagny B, Cudennec C. 2006. Gestion de l'eau en milieu aride: considérations physiques et sociales pour l'identification des territoires pertinents dans le Sud-Est tunisien. Dév Durable Territ. Économie Géographie Polit Droit Sociol. DOI: 10.4000/devel oppementdurable.1805.

Sala OE, Stuart Chapin III F, Armesto JJ, Berlow E, Bloomfield J, Dirzo R, Huber-Sanwald E, Huenneke LF, Jackson RB, Kinzig A, Leemans R, Lodge DM, Mooney HA, Oesterheld M, Poff NL, Sykes MT, Walker BH, Walker M et al. 2000. Global biodiversity scenarios for the year 2100. Science 287: 1770-1774.

Schneider A, Jost A, Coulon C, Silvestre M, Théry S, Ducharne A. 2017. Global-scale river network extraction based on highresolution topography and constrained by lithology, climate, slope, and observed drainage density. Geophys Res Lett 44: 2773-2781.

Sket B, Hou Z. 2018. Family Gammaridae (Crustacea: Amphipoda), mainly its Echinogammarus clade in SW Europe. Further elucidation of its phylogeny and taxonomy. Acta Biol Slovenica 61: 93-102.

Stöck M, Sicilia A, Belfiore NM, Buckley D, Lo Brutto S, Lo Valvo M, Arculeo M. 2008. Post-Messinian evolutionary relationships across the Sicilian channel: mitochondrial and nuclear markers link a new green toad from Sicily to African relatives. BMC Evol Biol 8: 56.

Stöck M, Dufresnes C, Litvinchuk SN, Lymberakis P, Biollay S, Berroneau M, Borzée A, Ghali K, Ogielska M, Perrin N. 2012. Cryptic diversity among Western Palearctic tree frogs: postglacial range expansion, range limits, and secondary contacts of three European tree frog lineages (Hyla arborea group). Mol Phylogenet Evol 65: 1-9.

Tierno de Figueroa JM, López-Rodríguez MJ, Fenoglio S, SánchezCastillo P, Fochetti R. 2013. Freshwater biodiversity in the rivers of the Mediterranean Basin. Hydrobiologia 719: 137-186.

WORMS. 2019. WoRMS - World Register of Marine Species.

Cite this article as: Ayati K, Hadjab R, Khammar H, Dhaouadi S, Piscart C, Mahmoudi E. 2019. Origin, diversity and distribution of freshwater epigean amphipods in Maghreb. Ann. Limnol. - Int. J. Lim. 55: 13 